Research Article

\title{
Waste Meretrix meretrix Shell as Adsorbent of Copper $\left(\mathrm{Cu}^{2+}\right)$
}

\author{
Encik Weliyadi $^{1 *}$, Afni Nidyasari ${ }^{1}$, Tri Paus Hasiholan Hutapea ${ }^{2}$ \\ ${ }^{1}$ Department of Water Resource Management, University of Borneo Tarakan, 77123, Indonesia \\ ${ }^{2}$ Department of Fisheries Product Technology, University of Borneo Tarakan, 77123, Indonesia
}

\section{Article history:}

Submission August 2020

Revised August 2021

Accepted May 2021

*Corresponding author:

E-mail:

weliyadianwar098@gmail.com

\begin{abstract}
Meretrix meretrix was found to be a very abundant waste at Amal Beach, Tarakan City. M. meretrix waste can reduce heavy metals, especially heavy metals copper $\left(\mathrm{Cu}^{2+}\right)$, by the adsorption process. Research has been carried out on M. meretrix as an adsorbent of heavy metals copper $\left(\mathrm{Cu}^{2+}\right)$ using the adsorption method of Shacker through chemical activation using $\mathrm{NaOH}$ bases. The SEM results showed that $M$. meretrix before activation had a rough pore surface that was still closed but M. meretrix after activation had a open pore surface that is why it could be used as an adsorbent. M. meretrix contains Al (Aluminum), which can be used as an adsorbent. The adsorption results showed that M. meretrix with activation in the Freundlich isotherm had the highest ability to absorb $\mathrm{Cu}^{2+}$ as much as 9,108 $\mathrm{mg} / \mathrm{g}$ compared to without activation only $0.051 \mathrm{mg} / \mathrm{g}$. It can be concluded that $M$. meretrix waste can be used as an absorbent of $\mathrm{Cu}^{2+}$ heavy metals.
\end{abstract}

Keywords: Adsorbent, Adsorption, Copper, Heavy metals, Meretrix meretrix

\section{Introduction}

The presence of high heavy metals in an area of water can reduce water quality and endanger the environment and aquatic organisms. The existence of minerals in water bodies can come from natural sources and activities carried out by humans. The content of heavy metals in the waters continues to increase along with increasing activities such as transportation, ports, the petroleum industry, and substantial population settlements. These anthropogenic activities produce bulky metal waste, including heavy metals copper $(\mathrm{Cu})$, which can affect the quality of the waters for the life of the organisms in it [1].

$\mathrm{Cu}$ is a transition metal (group I B) that is reddish, easy to stretch, and easily forged. Copper is a heavy metal that is toxic to living things [2]. This metal will be sustainably absorbed by aquatic biota if its presence in the waters is always available. One of the efforts to treat copper $(\mathrm{Cu})$ waste is by adsorption (absorption). Adsorption was chosen because it is a relatively simple method and can use natural material adsorbents such as shellfish waste. Research on heavy metal adsorption is car- ried out to reduce excessive heavy metals [3 - 7].

Shells containing calcium carbonate $\left(\mathrm{CaCO}_{3}\right)$, which undergo a calcination process, will produce calcite $(\mathrm{CaO})$. Calcite functions as an adsorbent on absorption [8]. The shell of Meretrix meretrix was very abundant on the Amal Beach, Tarakan City. The consumption of $M$. meretrix produces big shells waste which is not managed wisely. Waste of $M$. meretrix can be used as $\mathrm{Cu}^{2+}$ heavy metal adsorbent because clam and shell can remove a contaminant from the environment. This study aimed to determine the ability of shell waste as $\mathrm{Cu}^{2+}$ heavy metal adsorbent.

\section{Material and Methods}

The research procedure was started by doing M. meretrix shells sampling at Amal Beach. Samples were cleaned and dried. Then they were mashed and sieved with 80 mesh sieves. The samples were divided into two groups: (1) sample without activation and (2) with activation. The samples were activated by giving $0.1 \mathrm{~N} \mathrm{NaOH}$. As much as $50 \mathrm{~g}$ of shell powder was given with a 0.1 
$\mathrm{N} \mathrm{NaOH}$ as much as $250 \mathrm{~mL}$ (Sample : $\mathrm{NaOH}$ solution was $1: 5$ ), and it was stirred at a speed of $100 \mathrm{rpm}$. The activation process is carried out for 24 hours. Then the sample was filtered and dried in an oven at $50^{\circ} \mathrm{C}$. After drying, the conch shell powder was stored in a desiccator.

The surface acidity of the shell was determined by the acid-base titration method while the surface characterization of the adsorbent using Scanning Electron Microscopy-Energy Dispersive spectroscopy (SEM-EDS). In determining the adsorption capacity, the concentration of $\mathrm{Cu}$ metal ions used is $20-100 \mathrm{ppm}$. The concentration of the standard solution of Cu metal ions is $0-5 \mathrm{ppm}$. The determination of the concentration of $\mathrm{Cu}$ metal ions was based on the initial experiment of the adsorption process on $20 \mathrm{ppm} \mathrm{Cu}$ metal ions which resulted in the adsorption value in the standard solution adsorption range. Measurement of $\mathrm{Cu}$ metal ion concentration was carried out on the filtrate after the adsorption process using the Atomic Absorption Spectrophotometer. To determine the adsorption capability of the Freundlich equation, tests were performed using the following equation Atkins, 1997.

$$
\log W=\log k+\frac{1}{n \log C e}
$$

Information:

$$
\begin{aligned}
& \text { Log Ce : concentration of } \mathrm{Cu}^{2+} \text { ions in solution } \\
& \text { after adsorption }
\end{aligned}
$$

Log W : mass of $\mathrm{Cu}^{2+}$ ions absorbed per gram of adsorbent

n : Fruendlich constant

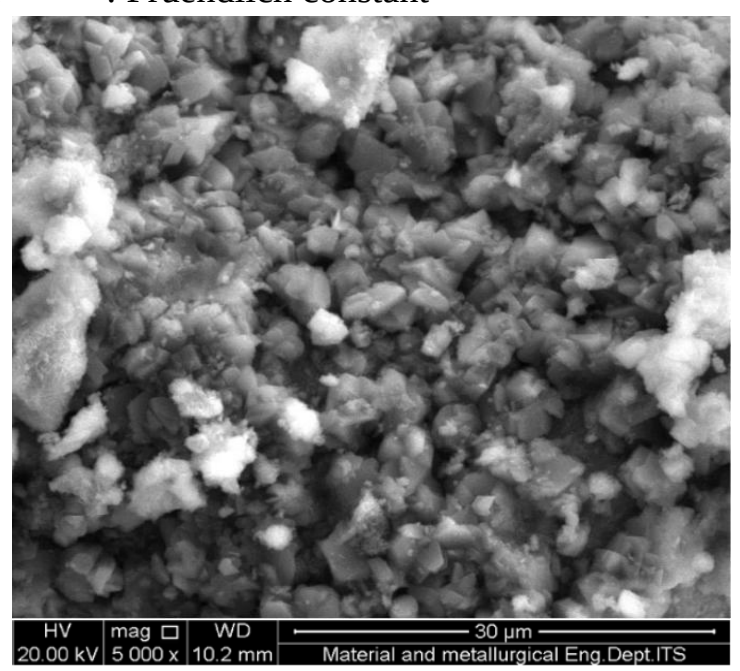

(A)
Log k : Adsorption Capacity (mg/g)

\section{Results and Discussions \\ Surface acidity of the Meretrix meretrix shell}

The results of surface acidity on the shells of Asiatic hard clam or kapah (in Bahasa) shells ( $M$. meretrix) before activation of $4.2 \mathrm{mmol} / \mathrm{g}$ and surface acidity on the rounds of kapah shells (M. meretrix) after activation of $7 \mathrm{mmol} / \mathrm{g}$. The surface of the conch shell (M. meretrix) before activation has the lowest surface acidity of $4.2 \mathrm{mmol} / \mathrm{g}$. This is because the shell of the kapah shell (M. meretrix) before activation still has many impurities on its surface. For samples of kapah shells (M. meretrix) after activation has an acidity of $7 \mathrm{mmol} / \mathrm{g}$. This is because activation with $\mathrm{NaOH}$ can dissolve impurities on the surface of the shell so that the surface pores can open. The value of surface acidity affects the effectiveness of adsorption. The more acidity the copper adsorption by adsorbent is also higher because it has many active sites [9]. The adsorbent pore becomes homogeneous, and the ability to adsorb adsorbate is increased [10]. So that from this study, the head of a mussel shell ( $M$. meretrix) after activation is more effectively used as an adsorbent than the head of a mussel shell ( $M$. meretrix) without activation.

\section{Surface shell characterization (Meretrix mere- trix)}

The characterization was carried out using a Scanning Electron Microscope (SEM), which aims to determine the surface morphological characteristics of the adsorbent by comparing the surface of the adsorbent before and after activation.

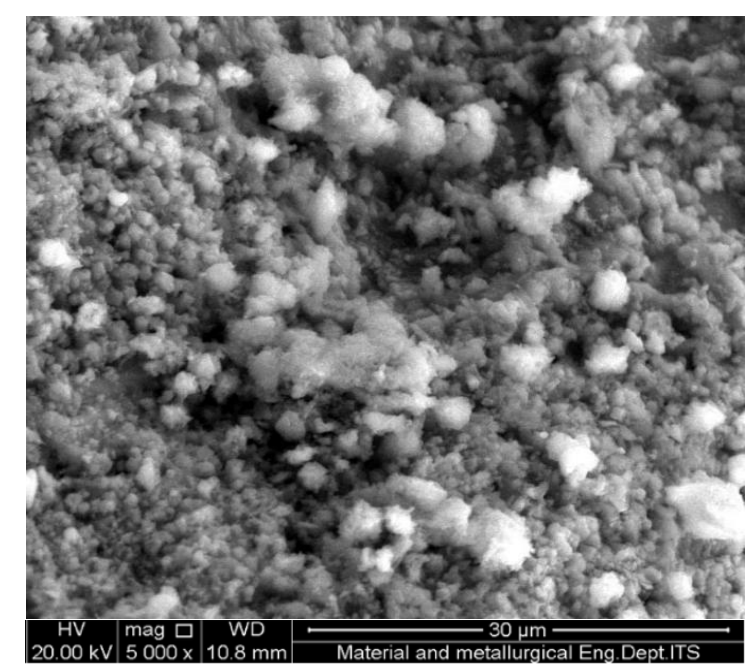

(B)

Figure 1. Surface Morphology of the Shell (M. meretrix) Before (A) and After (B) Activation 
The results of the surface characterization of the clamshells ( $M$. meretrix) can be seen with a magnification of 5000 times in Figures 1.

From the results obtained can be seen differences in the surface morphology of the adsorbent before and after activation. It appears that the surface of the adsorbent after activation is more homogeneous than before activation with an average surface area of $1.8 \mu \mathrm{m}$. This is presumably on the surface of the shell of the kapah shell $(M$. meretrix) before activation still contains impurities. The addition of $\mathrm{NaOH}$ in the activation process can reduce contaminants that are still present in the adsorbent. Adsorbent consists of layers overlapping one another to form a pore. Where the adsorbent pores are usually, there are impurities in

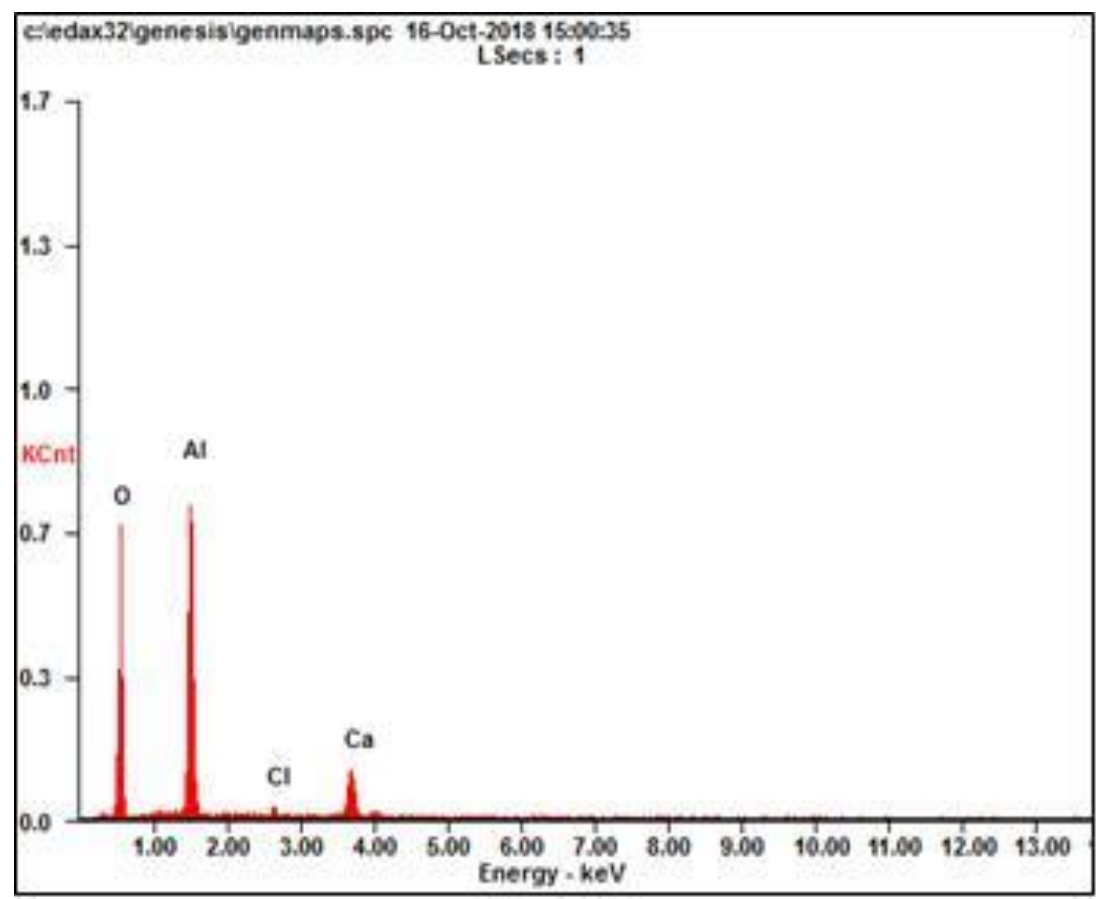

(A)

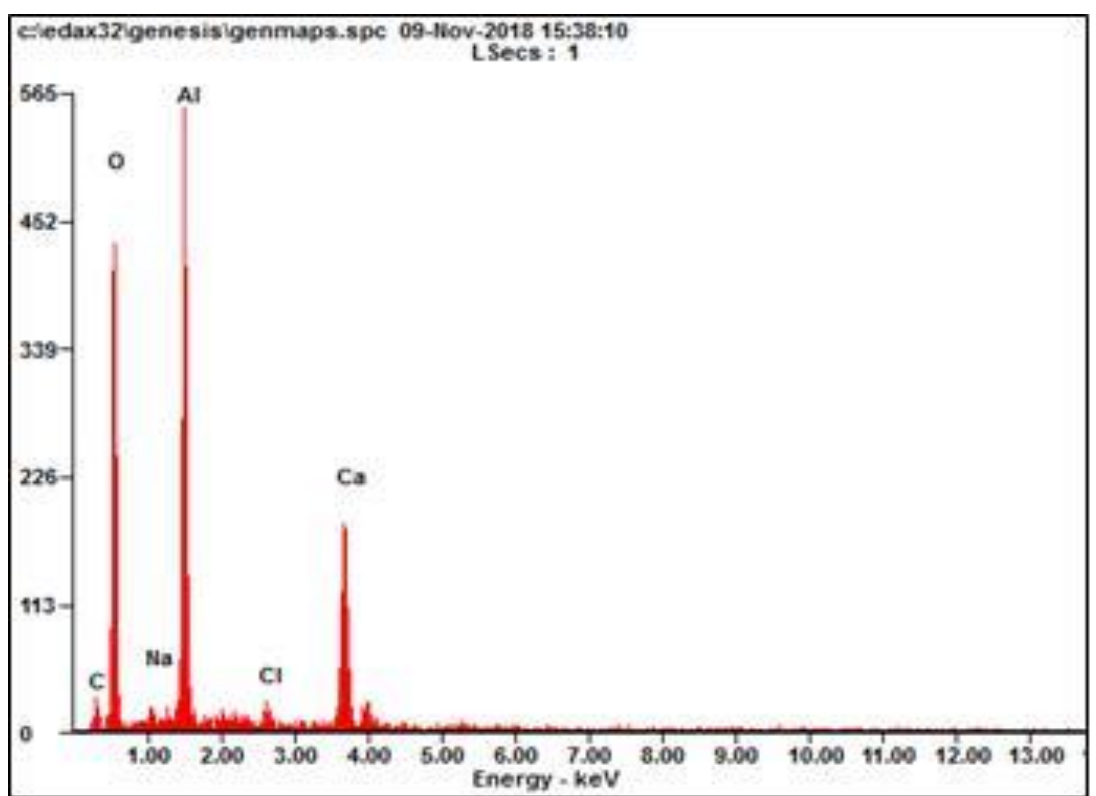

(B)

Figure 2. Graphs of composition of shells of the shell (M. meretrix) before activation (A) and after activation (B) 


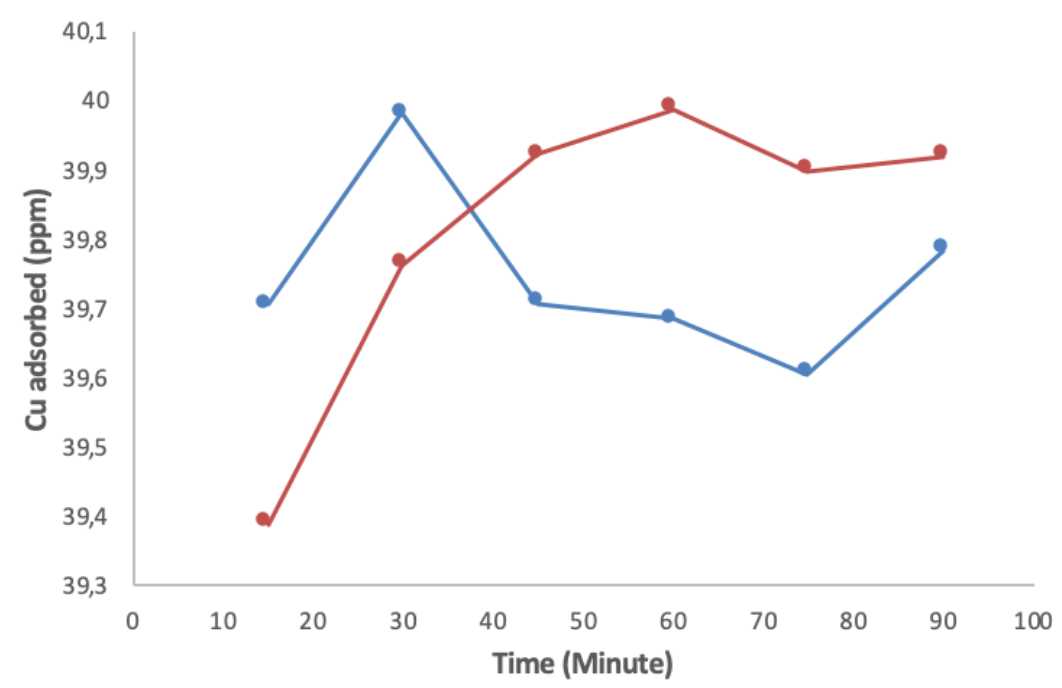

Figure 3. Contact time graph of adsorbent absorption before (red line) and after (blue line) activation of $\mathrm{Cu}^{2+}$

the form of inorganic minerals and metal oxides that cover the pores. During the activation process, the pollutants also evaporate, causing the pores to get more significant [11] The results of the analysis of the composition contained in the shells of kapah (M. meretrix) before and after activation can be seen in Figure 2 which shows that there are $\mathrm{O}$ (oxygen), $\mathrm{Al}$ (Aluminum), $\mathrm{Cl}$ (Chlorine) and $\mathrm{Ca}$ (Ca) Calcium). The highest yield found in the shells of kapah (M. meretrix) is Al. The results of the analysis of the composition contained in the shells of kapah shells (M. meretrix) before and after activation shows that there are $\mathrm{O}, \mathrm{Al}$, and $\mathrm{Ca}$. The highest yield found in the shells of kapah (M. meretrix) is Al. Characterization was carried out on kapah shells (M. meretrix) samples before and after activation. The results of the analysis of the composition of kapah shells (M. meretrix) samples before activation were dominated by $\mathrm{O}, \mathrm{Al}, \mathrm{Cl}$, and $\mathrm{Ca}$, with the highest yield, namely $\mathrm{Al}$ content. The results of the analysis of the composition of kapah shells (M. meretrix) samples after activation are dominated by $\mathrm{O}, \mathrm{Al}, \mathrm{Cl}$, and $\mathrm{Ca}$, with the highest yield, namely $\mathrm{Al}$ content. The increase in $\mathrm{Al}$ composition is caused by the loss of the impurity bonds that cover the $\mathrm{Al}$ on the adsorbent. The increase in $\mathrm{Al}$ composition is expected to increase the active site of the adsorbent [12 - 15].

The aluminum composition contained in the adsorbent affects the effectiveness of the adsorbent to absorb metal ions [16 - 18]. The results of determining the maximum time on the shells of kapah shells (M. meretrix) before activation can be seen in Figure 3, which shows that the highest absorption time of $\mathrm{Cu}^{2+} 40 \mathrm{ppm}$ is at 30 minutes with the absorption of $39.9818 \mathrm{ppm}$.

At the maximum time, a determination is done using the shell of the kapah shell (M. meretrix) activation and without activation. Using $\mathrm{Cu}^{2+} 40$ ppm solution over a span of $15,30,45,60,75$, and 100 minutes. From the measurement results, the maximum time obtained by the mussel shells $(M$. meretrix) without activation absorbing $\mathrm{Cu}^{2+}$ is 30 minutes, and the kapah shells (M. meretrix) with activation is 60 minutes. This maximum time absorption is due to the number of active sides in the shell being fully used so that there is no more active side that can bind $\mathrm{Cu}^{2+}$, and the shell pores are also full by $\mathrm{Cu}^{2+}$.

\section{The absorption ability of $\mathrm{Cu}^{2+}$ by kapah shell shells (M. meretrix) in the adsorption isotherm}

Adsorption capacity is the ability of an adsorbent to absorb adsorbate. In this research, various concentrations of $\mathrm{Cu}^{2+}$ solutions are used to determine the adsorption capacity. The level of $\mathrm{Cu}^{2+}$ solution used was 20, 40, 60, 80, and $100 \mathrm{ppm}$. The flow time used is the maximum time obtained at the determination of the maximum time, namely in the shell of the conch shell (M. meretrix) without activation for 30 minutes and on an eggshell shell (M. meretrix) with 60 minutes activation, after that, analyzed at AAS. So we get the remaining $\mathrm{Cu}^{2+}$ concentration. The results are then processed to obtain the adsorption capacity from the results obtained. This study uses the Freundlich adsorption isotherms. In kapah shells ( $M$. meretrix) with out activation using the Freundlich adsorption iso 


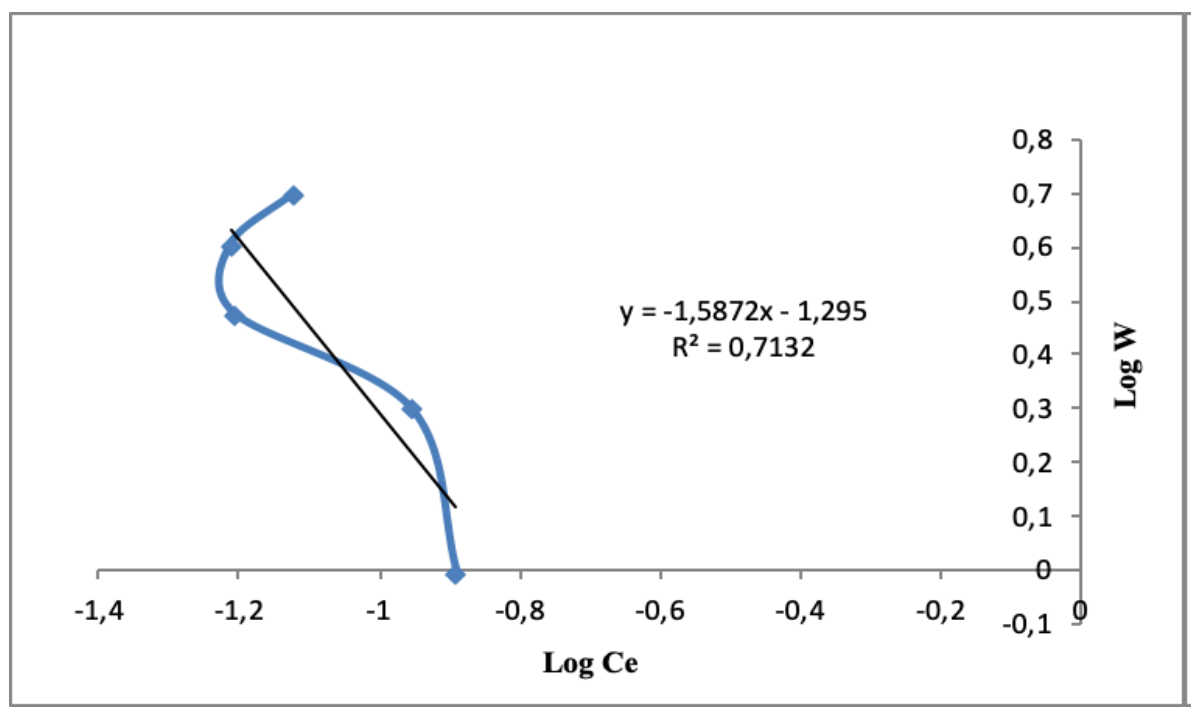

(A)

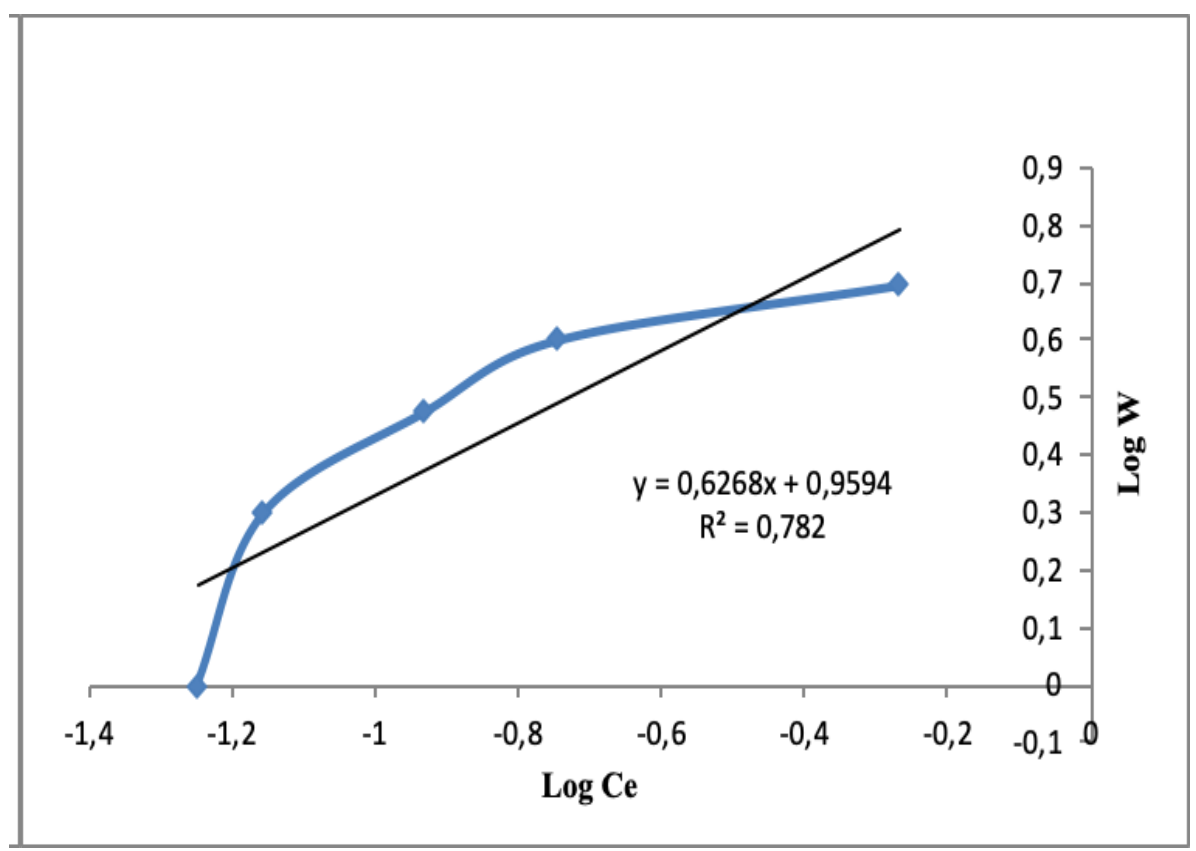

(B)

Figure 4. Freundlich isotherm adsorption graph of $\mathrm{Cu}^{2+}$ by kapah shells (M. meretrix) (A) without activation and (B) with activation

therm. Because this isotherm shows a better value than other isotherms, so this isotherm is used. In the Freundlich isotherm, the data obtained is entered in a graph. The graph on the Freundlich isotherm has components $\mathrm{y}=\log \mathrm{W}$ and $\mathrm{x}=\log \mathrm{Ce}$, where $\mathrm{W}$ is $\mathrm{Cu}^{2+}$ absorbed in the shell $(\mathrm{mg} / \mathrm{g})$, while Ce is the residual concentration (ppm). After knowing the value, The $\log \mathrm{W}$ and the Log Ce value are entered in a graph, as shown in Figure 4.

From the graph the equation $\mathrm{y}=-1.5872 \mathrm{x}$ 1.295 was obtained with the value $\mathrm{R}^{2}=0.7132$. In the Freundlich equation $\log W=\log k+(1 / n) \log$ $\mathrm{Ce}$, where $1 / \mathrm{n}$ is the slope and $\log \mathrm{k}$ is the intercept. If $\mathrm{k}$ is the adsorption capacity of the shell ( $M$. meretrix) without activation, then the inverse of $\log \mathrm{k}$ is 0.0507 . adsorption for shellfish without activation was obtained at $0.051 \mathrm{mg} / \mathrm{g}$. The conclusion obtained is that 1 gram of adsorbent shells (M. meretrix) without activation can absorb $\mathrm{Cu}^{2+}$ as much as $0.051 \mathrm{mg}$.

From the graph the equation $\mathrm{y}=0.6268 \mathrm{x}+$ 0.9594 with $R^{2}=0.782$ is obtained. In the Freun- 
dlich equation, the adsorption capacity for shells with activation was obtained at 9,108 $\mathrm{mg} / \mathrm{g}$. The conclusion obtained is that 1 gram of adsorbent from the shells of the mussels (M. meretrix) with activation can absorb $\mathrm{Cu}^{2+}$ as much as 9,108 $\mathrm{mg}$. The increase in adsorption capacity is caused by the opening of the larger active site so that the adsorbent binds more adsorbate. It causes the adsorption capacity will increase, while the decrease in adsorption capacity is caused by the active site of the adsorbent, which is not all bound to the adsorbate [19].

\section{Conclusion}

Shells kapah (M. meretrix) without activation or activation can be used as an adsorbent because, based on research in addition to having $\mathrm{Ca}$ (Calcium) also has Al (Aluminum). Kapah shell ( $M$. meretrix) without activation in the Freundlich Isotherm can absorb $\mathrm{Cu}^{2+}$ as much as $0.051 \mathrm{mg} / \mathrm{g}$. Whereas in the case of kapah shells (M. meretrix) with activation in the Freundlich isotherm has the highest ability to absorb $\mathrm{Cu}^{2+}$ which is 9,108 $\mathrm{mg} / \mathrm{g}$. So based on research, kapah shell shells ( $M$. meretrix), which through the activation process, are more effective in absorbing heavy metal copper $\left(\mathrm{Cu}^{2+}\right)$ compared to kapah shell shells (M. meretrix) without going through the activation process.

\section{References}

1. Lestari L, Edward E (2010) Dampak Pencemaran Logam Berat Terhadap Kualitas Air Laut Dan Sumberdaya Perikanan (Studi Kasus Kematian Massal Ikan-Ikan di Teluk Jakarta). Makara Journal of Science 8 (2): 52 - 58. doi: 10.7454/Mss.V8i2.414.

2. Ochoa-Herrera V, León G, Banihani Q et al. (2011) Toxicity of copper(II) ions to microorganisms in biological wastewater treatment systems. The Science of the total environment 15 (412-413): 380-385. doi: 10.1016/j.scitotenv.2011.09.072.

3. Tangio JS (2013) Adsorpsi Logam Timbal (Pb) Dengan Menggunakan Biomassa Enceng Gondok (Eichhorniacrassipes). Jurnal Entropi 8 (1): 500 - 506.

4. Wan Ngah WS, Teong LC, Hanafiah MAKM (2011) Adsorption of dyes and heavy metal ions by chitosan composites: A review. Carbohydrate Polymers 83 (4): 14461456. doi: 10.1016/j.carbpol.2010.11.004.

5. Hutapea TPH, Yusuf B, Purba R (2016) Pemanfaatan Batu Padas Dalam Mengadsorpsi Logam Berat Pb (Ii) Di Perairan. Jurnal Harpodon Borneo 9 (2): 107 - 110. doi: 10.35334/harpodon.v9i2.166.
6. Emelda L, Putri SM, Ginting S (2013) Pemanfaatan Zeolit Alam Teraktivasi untuk Adsorpsi Logam Krom (Cr3+). Jurnal Rekayasa Kimia dan Lingkungan 9 (4): 166 - 170. doi: 10.23955/rkl.v9i4.1229.

7. Hutapea TPH, Paramitha A, Rachmawani D (2019) Telescopium telescopium Shell Waste as Fe (II) Adsorbent. Jurnal Sumberdaya Akuatik Indopasifik 3 (2): 115 - 122. doi: 10.46252/jsai-fpik-unipa.

8. R. Asyhar (2012) Adsorption Isotherms of Phenol Onto Adsorbents Derived from Egg Shell and Palm-Oil Shell. Jurnal Natur Indonesia 13 (3): 276 - 280. doi: 10.31258/jnat.13.3.276-280.

9. Wu S, Cen JP (2001) Modification of a commercial activated carbon for metal adsorption by several approaches. p. 4.

10. Syauqiah I, Amalia M, Kartini HA (2011) Analisis Variasi Waktu Dan Kecepatan Pengaduk Pada Proses Adsorpsi Limbah Logam Berat Dengan Arang Aktif. Infoteknik 12 (1): 11 - 20.

11. Idrus R, Lapanporo RP, Putr YS (2013) Pengaruh Suhu Aktivasi Terhadap Kualitas Karbon Aktif Berbahan Dasar Tempurung Kelapa. Prisma Fisika 1 (1): 50 - 55. doi: 10.26418/pf.v1i1.1422

12. Huang Y, Li S, Chen J et al. (2014) Adsorption of Pb(II) on mesoporous activated carbons fabricated from water hyacinth using $\mathrm{H} 3 \mathrm{PO} 4$ activation: Adsorption capacity, kinetic and isotherm studies. Applied Sirface Science 293: 160-168. doi: 10.1016/j.apsusc.2013.12.123.

13. Karagoz S, Tay T, Ucar S, Erdem M (2008) Activated carbons from waste biomass by sulfuric acid activation and their use on methylene blue adsorption. Bioresource Technology 99 (14): 6214-6222. doi: 10.1016/j.biortech.2007.12.019.

14. Tsai WT, Chang CY, Lin MC et al. (2001) Adsorption of acid dye onto activated carbons prepared from agricultural waste bagasse by $\mathrm{ZnCl} 2$ activation. Chemosphere 45 (1): 51-58. doi: 10.1016/S0045-6535(01)00016-9.

15. Foo KY, Hameed BH (2012) Coconut husk derived activated carbon via microwave induced activation: Effects of activation agents, preparation parameters and adsorption performance. Chemical Engineering Journal 184: 57-65. doi: 10.1016/j.cej.2011.12.084.

16. Nguyen TMT, Do TPT, Hoang TS et al. (2018) Adsorption of Anionic Surfactants onto Alumina: Characteristics, Mechanisms, and Application for Heavy Metal Removal. International Journal of Polymer Science 2018: 111. doi: $10.1155 / 2018 / 2830286$.

17. Mahapatra A, Mishra BG, Hota G (2013) Electrospun $\mathrm{Fe} 2 \mathrm{O} 3-\mathrm{Al} 2 \mathrm{O} 3$ nanocomposite fibers as efficient adsorbent for removal of heavy metal ions from aqueous solution. Journal of Hazard Material 258-259: 116-123. doi: 10.1016/j.jhazmat.2013.04.045.

18. H. Chen, Luo J, Wang X et al. (2018) Synthesis of $\mathrm{Al2O} /$ carbon composites from wastewater as superior adsorbents for $\mathrm{Pb}(\mathrm{II})$ and $\mathrm{Cd}(\mathrm{II})$ removal. Microporous Mesoporous Mater 255: 69-75. doi: 10.1016/j.micromeso.2017.07.023.

19. Rahmawati D (2006) Adsorpsi senyawa residu klorin pada karbon aktif termodifikasi zink klorida. Thesis, Institut Pertanian Bogor. 